\title{
Powerbank Piezoelektrik Menggunakan Tekanan Tangan
}

\author{
Reggya Mayang Ratih ${ }^{1}$, Muhamad Ibnu Yasyak ${ }^{2}$, Hijiril Nugroha $^{3}$, Umi Fadlilah ${ }^{4}$ \\ Program Studi Teknik Elektro \\ Universitas Muhammadiyah Surakarta \\ Surakarta, Indonesia \\ d400180132@student.ums.ac.id ${ }^{1}$,d400170137@student.ums.ac.id², b200174322@student.ums.ac.id ${ }^{3}$,umi.fadlilah@ums.ac.id ${ }^{4}$
}

\begin{abstract}
Abstraksi - Perkembangan smartphone yang semakin canggih membuat penggunaan daya baterai smartphone semakin meningkat. Dilatarbelakangi oleh tidak terbatasnya aktivitas outdoor maupun indoor yang selalu membutuhkan smartphone dalam kondisi on dan terbatasnya terminal listrik serta terbatasnya daya baterai handphone yang cepat habis membuat keberadaan powerbank menjadi solusi dari permasalahan tersebut. Fungsi dari powerbank tidak lain adalah untuk menyimpan daya cadangan, yang mana bisa digunakan disaat jauh dari jangkauan listrik. Akan tetapi powerbank pada umumnya belum dapat memecahkan masalah secara maksimal, karena apabila daya yang tersimpan dalam powerbank habis, maka powerbank perlu diisi daya kembali. Dalam pengisian daya powerbank membutuhkan energi lagi dari sumber listrik. Artikel ini mendeskripsikan tentang powerbank piezoelektrik yang dapat menghasilkan tegangan dan arus listrik yang dapat digunakan untuk mengisi daya handphone dengan cara ditekan menggunakan tangan.
\end{abstract} Daya

Katakunci - Piezoelektrik; Smartphone; Tegangan; Tekanan;

\section{PENDAhUluan}

Maraknya merek smartphone yang menawarkan berbagai fitur canggih membuat orang betah menghabiskan banyak waktu di depan smartphone (handphone pintar) dan tak bisa lepas dari perangkat itu. Penelitian dari Digital GFK Asia, perempuan Indonesia setidaknya menghabiskan waktu selama 5,6 jam/hari dengan smartphone mereka. Adapun pria Indonesia, menghabiskan waktu menggunakan smartphone selama 5,4 jam/hari dan membuka sekitar 47 aplikasi atau alamat website. Secara rata-rata orang Indonesia menghabiskan waktu dengan smartphone selama 5,5 jam/hari dan membuka 46 aplikasi dan alamat website [1]. Dari penelitian di atas menunjukkan smartphone dengan kondisi on dalam waktu yang lama sedangkan baterai smartphone kapasitasnya terbatas, apabila daya baterai habis maka pengguna smartphone harus mengisi daya dari sumber listrik agar tetap bisa mengoperasikan handphone. Sedangkan terminal listrik yang tersedia jumlahnya jauh lebih sedikit dari pengguna handphone. Hal tersebut menjadi kendala bagi mereka yang lebih sering melakukan aktivitas di luar ruangan karena jauh dari sumber listrik rumahan atau terbatasnya terminal listrik.
Oleh sebab itu powerbank sangat cocok bagi mereka yang sering berada di luar ruangan dan jauh dari sumber energi listrik. Powerbank berfungsi sebagai penyimpan daya atau dapat dianalogikan sebagai baterai. Namun powerbank juga sama halnya dengan baterai handphone apabila daya yang tersimpan habis maka powerbank perlu di charge dan hal ini membutuhkan energi lagi dari sumber listrik. Banyak metode yang telah didapatkan dari permasalahan tersebut seperti powerbank solar cell, powerbank ini mengubah cahaya matahari menjadi kerja listrik melalui photovoltaic effect [2]. Akan tetapi powerbank ini masih mempunyai kelemahan yaitu sangat bergantung pada panas matahari dan keadaan cuaca. Semakin besar intensitas cahaya matahari secara proporsional akan menghasilkan arus yang besar [3]. Powerbank solar cell akan bekerja secara optimal dalam keadaan terkena panas matahari langsung tanpa mendung sedangkan panas matahari tidak bisa dikontrol oleh manusia dan tidak semua negara mengalami iklim atau cuaca panas terus-menerus.

Berdasarkan dua uraian paragraph di atas penulis mengupayakan pemecahan masalah pengisian daya powerbank menggunakan material piezoelektrik. Material piezoelektrik adalah suatu bahan yang apabila diberikan tekanan mekanik akan menghasilkan medan listrik, sebaliknya apabila medan listrik diterapkan pada bahan piezoelectric akan terjadi deformasi mekanik [4]. Efek piezoelektrik terjadi jika medan listrik terbentuk ketika material dikenai tekanan mekanik [5]. Dari penelitian [6] didapatkan hasil bahwa gelombang yang dihasilkan piezoelektrik adalah sinusoidal atau AC, dengan gelombang positif lebih besar dibandingkan gelombang negatif dikarenakan momentum tegangan mekanik lebih besar daripada momentum regangan mekanik. Oleh karena itu, dalam pembuatan alat powerbank piezoelektrik diperlukan rangkaian penyearah. Penyearah gelombang atau rectifier adalah bagian dari catu daya yang berfungsi sebagai pengubah sinyal tegangan AC menjadi tegangan DC [7]. Penelitian yang dilakukan oleh [8] juga menyatakan bahwa nilai tegangan dan arus keluaran piezoelektrik yang terukur berbeda-beda pada setiap pengukurannya, hal ini disebabkan energi mekanik ketika dilakukan penekanan bervariasi. Oleh sebab itu dalam rangkaian powerbank piezoelektrik akan ditambahkan converter boost yang berfungsi menaikkan tegangan dan menstabilkan tegangan. 
Penggunaan piezoelektrik untuk sumber daya powerbank adalah dikarenakan piezoelektrik tidak bergantung pada terminal listrik dan variabel yang tidak bisa dikontrol oleh pengguna secara langsung. Tujuan pembuataan powerbank ini adalah agar pengguna bisa mengontrol langsung pemberian tekanan langsung kepada piezolektrik dimanapun dan kapanpun untuk mengisi baterai powerbank.

\section{METODE}

\section{A. Perangkaian Piezoelektrik Secara Seri dan Paralel}

Untuk dijadikan sebagai generator yang menghasilkan arus dan tegangan maka piezoelektrik disusun secara seri atau paralel. Dari penyusunan seri atau paralel akan didapatkan keluaran yang terbesar, dari keluaran tersebut maka dipilihlah susunan yang tepat yang digunakan dalam pembuatan powerbank piezoelektrik.

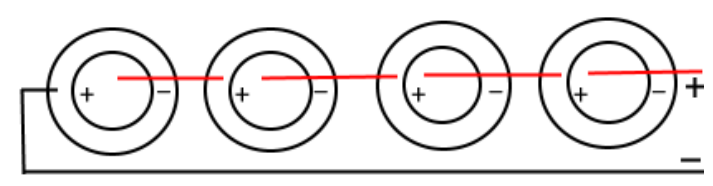

Gambar 1. Piezoelektrik Secara Seri

Penyusunan piezoelektrik secara seri dengan cara menghubungkan kutub positif piezoelektrik pertama dengan kutub negatif piezoelektrik kedua, kutub positif piezoelektrik kedua dihubungkan dengan kutub negatif piezoelektrik ketiga, dan seterusnya [9]. Pada gambar 3 rangkaian seri dapat dijelaskan bahwa jumlah total daya yang masuk suatu titik cabang sama dengan jumlah daya yang keluar tiap titik cabang tersebut, sehingga didapat persamaan sebagai berikut :

$$
\begin{aligned}
& E_{\text {total }}=E_{1}=E_{2}=E_{3}=E_{4} \\
& I_{\text {total }}=I_{1}+I_{2}+I_{3}+I_{4}
\end{aligned}
$$

Keterangan : $\mathrm{E}=$ daya $(\mathrm{W})$

$$
\mathrm{I}=\operatorname{arus}(\mathrm{A})
$$

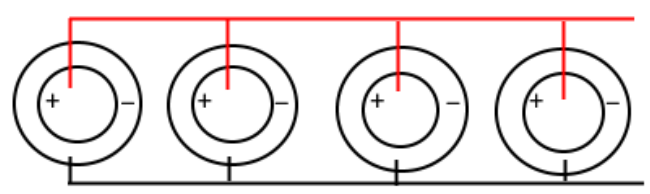

Gambar 4. Piezoelektrik Secara Paralel

Pada Gambar 4 dapat dijelaskan bahwa rangkaian piezoelektrik secara paralel jumlah total daya yang masuk suatu titik cabang adalah penjumlahan daya yang keluar tiap titik cabang tersebut sehingga didapat persamaan sebagai berikut:

$$
\begin{array}{r}
E_{\text {total }}=E_{1}+E_{2}+E_{3}+E_{4} \\
I_{\text {total }}=I_{1}=I_{2}=I_{3}=I_{4} \\
\text { Keterangan }: \\
\mathrm{E}=\operatorname{daya}(\mathrm{W}) \\
\mathrm{I}=\operatorname{arus}(\mathrm{A})
\end{array}
$$

Penyusunan piezoelektrik secara paralel dilakukan dengan cara menghubungkan kutub positif empat piezoelektrik menjadi satu, dan menghubungkan kutub-kutub negatif empat piezoelektrik menjadi satu.

\section{B. Penambahan Rangkaian Penyearah Jembatan}

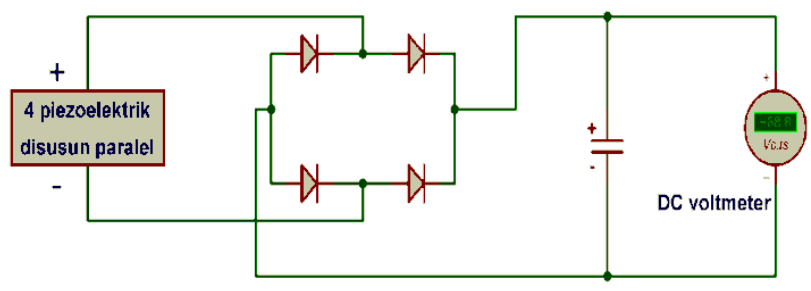

Gambar 3. Pengukuran Output Rangkaian Penyearah dengan Filter C

Penambahan rangkaian penyearah setelah piezoelektrik bertujuan untuk menyearahkan gelombang sinusoidal dari piezoelektrik menjadi sinyal tegangan DC. Pada penyearah gelombang tipe jembatan untuk setiap siklus tegangan $\mathrm{AC}$ hanya ada 2 dioda yang meneruskan arus, sedangkan 2 dioda lainnya bersifat isolator.

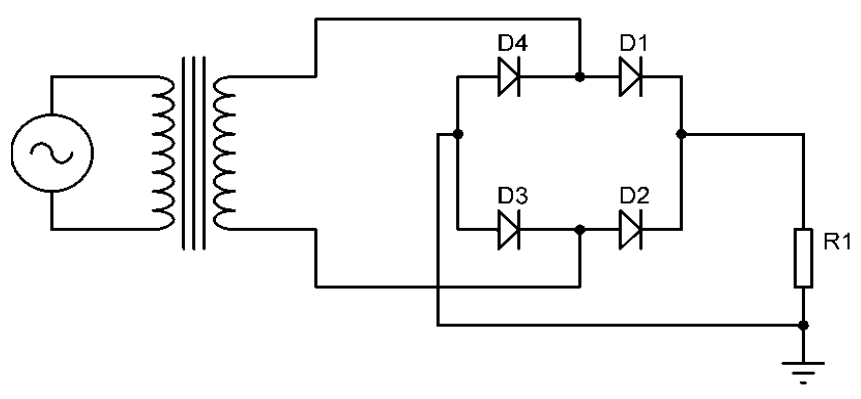

Gambar 4. Rangkaian Penyearah Jembatan

Prinsip kerja rangkaian penyearah jembatan adalah ketika mendapat bagian positif dari siklus sinyal AC, maka arus akan mengalir melalui D1 menuju beban dan kembali melalui D3. Pada saat bersamaan juga, D2 dan D4 mengalami reverse bias sehingga tidak ada arus yang mengalir. Ketika siklus negatif, arus akan mengalir melalui D2 dan D4 sedangkan D1 dan D3 mengalami reverse bias tidak ada arus yang melaluinya atau bersifat isolator.

\section{Penambahan Converter Boost dan Saklar}

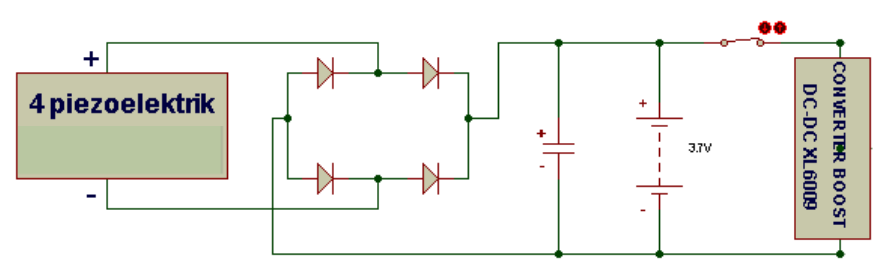

Gambar 5. Penambahan Converter Boost dan Saklar

Perangkaian dilakukan dengan merangkai 4 piezoelektrik dengan keluaran terbesar, yang digabungkan dengan rangkaian penyearah jembatan dengan filter $\mathrm{C}$ dengan tujuan menyearahkan gelombang sinusoidal piezoelektrik menjadi gelombang DC, setelah itu menghubungkan rangkaian ke baterai dan modul booster XL6009 dengan penambahan saklar sebelum terhubung USB. Penggunaan modul booster XL6009 
menghasilkan operasi yang stabil pada berbagai macam tegangan suplai dan output yang memiliki fitur sebagai berikut [10]:
a) Tegangan masukan $5-32 \mathrm{~V}$.
b) Switching frequency $320-480 \mathrm{kHz}$.
c) Tegangan output maksimum $60 \mathrm{~V}$.
d) Arus maksimum $4 \mathrm{~A}$.
e) Efisiensi maksimum $94 \%$.
f) Duty cycle maksimum $90 \%$

Penambahan saklar setelah converter boost bertujuan untuk mengetahui pengaruh kondisi saklar terbuka atau tertutup terhadap tegangan output pada converter boost maupun pada kapasitor.

\section{HASIL DAN PEMBAHASAN}

\section{A. Pengukuran Output Rangkaian Paralel dan Seri Piezoelektrik}

Tahapan yang dilakukan dalam pengukuran output piezoelektrik adalah pengukuran tegangan 4 buah piezoelektrik tersusun secara paralel dan seri dengan pemberian penekanan oleh tangan. Pengambilan data dilakukan setiap kali diberi tekanan dicatat tegangan dan arus yang terukur oleh multimeter. Adapun hasil pengukuran tegangan dan arus dari pengukuran yang dilakukan disajikan pada Tabel 1. Berikut hasil yang diperoleh dari pengukuran yang dilakukan.

TABEL I. TEgangan Dan ARUS Keluaran PiEZOELEKTRIK RANGKAIAN PARALEL DAN SERI

\begin{tabular}{|c|c|c|c|c|}
\hline \multirow{2}{*}{$\begin{array}{c}\text { Tekanan } \\
\text { ke- }\end{array}$} & \multicolumn{2}{|c|}{ Rangkaian Paralel } & \multicolumn{2}{c|}{ Rangkaian Seri } \\
\cline { 2 - 5 } & Tegangan & Arus & Tegangan & Arus \\
\hline 1 & 1,3 volt & $2,4 \mathrm{~mA}$ & 0,16 volt & $0,07 \mathrm{~mA}$ \\
\hline 2 & 1,7 volt & $3,0 \mathrm{~mA}$ & 0,17 volt & $0,64 \mathrm{~mA}$ \\
\hline 3 & 3,5 volt & $3,7 \mathrm{~mA}$ & 0,35 volt & $0,7 \mathrm{~mA}$ \\
\hline
\end{tabular}

Berdasarkan hasil pengukuran Tabel 1 pada 4 piezoelektrik tipe buzzer yang disusun secara seri dan paralel didapatkan hasil bahwa tegangan dan arus yang dihasilkan rangkaian paralel lebih besar daripada rangkaian seri. Penelitian oleh [11] menyatakan alasan kenapa rangkaian paralel menghasilkan tegangan yang lebih tinggi karena rangkaian paralel dapat mengumpulkan arus secara kontinu meskipun masukannya tidak kontinu sedangkan rangkaian seri sering mengalami penurunan tegangan akhirnya arus yang masuk tidak kontinu.

\section{B. Pengukuran Tegangan pada Kapasitor}

Berdasarkan hasil pengukuran pada A didapatkan hasil bahwa rangkaian paralel piezoelektrik lebih besar menghasilkan tegangan sehingga dalam pengukuran tegangan pada kapasitor menggunakan rangkaian piezoelektrik yang disusun secara paralel. Adapaun hasil dari pengukuran tersebut sebagai berikut.
TABEL II. Pengukuran Tegangan Keluaran Pada KaPasitor

\begin{tabular}{|c|c|}
\hline Jumlah Tekanan & Tegangan di Kapasitor \\
\hline 50 & 0,80 volt \\
\hline 100 & 1,50 volt \\
\hline 150 & 1,75 volt \\
\hline
\end{tabular}

Berdasarkan hasil pengukuran Tabel 2 dapat diketahui setiap piezoelektrik ditekan oleh telapak tangan maka ada kenaikan tegangan. Semakin banyak tekanan yang dilakukan maka tegangan akan semakin besar begitu juga dengan energi yang disimpan kapasitor juga semakin besar. Pada rangkaian ini banyaknya tekanan berbanding lurus dengan besarnya tegangan yang terukur di kapasitor. Hasil dari pengujian tersebut juga sama dengan hasil penelitian yang dilakukan oleh [12]. Dalam selang waktu yang sama, besarnya nilai tegangan yang dihasilkan piezoelektrik sebanding dengan besarnya frekuensi ketukan mekanik yang diberikan pada piezoelektrik.

\section{Pengukuran Tekanan Pada Kapasitor dan Converter Boost dalam Kondisi Saklar Terbuka dan Tertutup}

Pengukuran kali ini dilakukan dengan dua kondisi yaitu saklar tertutup dan saklar terbuka, yang bertujuan untuk mengetahui pengaruh kondisi saklar pada penambahan converter boost DC-DC XL6009 terhadap tegangan yang dihasilkan.

Adapun hasil pengukuran tersebut disajikan dalam Gambar 6, Gambar 7, Tabel 3 dan Tabel 4, sebagai berikut:

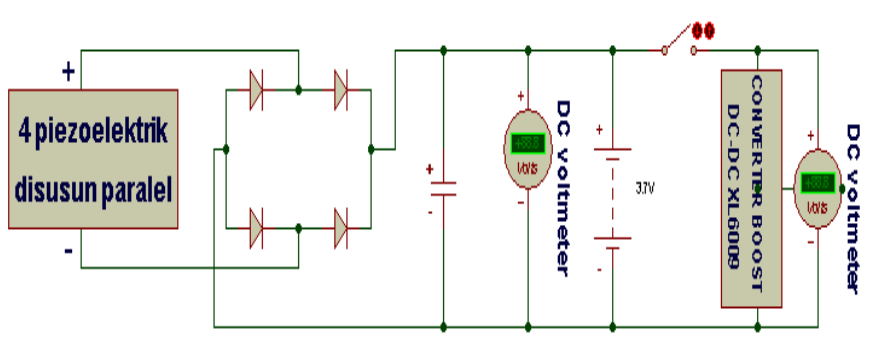

Gambar 6. Pengukuran Tegangan Rangkaian dengan Kondisi Saklar Terbuka

TABEL III. TEGANGAN DI KAPASITOR DAN CONVERTER BOOST KONDISI SAKLAR TERBUKA

\begin{tabular}{|c|c|c|c|}
\hline $\begin{array}{c}\text { Jumlah } \\
\text { Tekanan }\end{array}$ & $\begin{array}{c}\text { Tegangan di } \\
\text { Kapasitor }\end{array}$ & $\begin{array}{c}\text { Tegangan In } \\
\text { di Converter } \\
\text { Boost }\end{array}$ & $\begin{array}{c}\text { Tegangan Out } \\
\text { di Converter } \\
\text { Boost }\end{array}$ \\
\hline 100 & 1,5 volt & 3,98 volt & 6,45 volt \\
\hline 200 & 1,73 volt & 3,98 volt & 6,45 volt \\
\hline 300 & 2,30 volt & 3,98 volt & 6,45 volt \\
\hline
\end{tabular}




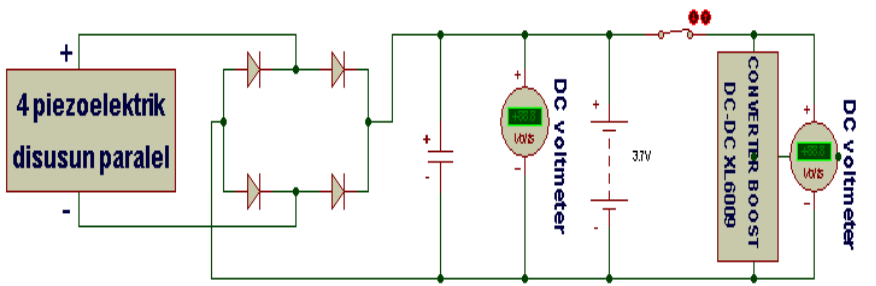

Gambar 7. Pengukuran Tegangan Rangkaian dengan Kondisi Saklar Tertutup

TABEL IV. TEGANGAN Di KAPASITOR DAN CONVERTER BOOST KONDISI SAKLAR TERTUTUP

\begin{tabular}{|c|c|c|c|}
\hline $\begin{array}{c}\text { Jumlah } \\
\text { Tekanan }\end{array}$ & $\begin{array}{c}\text { Tegangan di } \\
\text { Kapasitor }\end{array}$ & $\begin{array}{c}\text { Tegangan In } \\
\text { di Converter } \\
\text { Boost }\end{array}$ & $\begin{array}{c}\text { Tegangan Out } \\
\text { di Converter } \\
\text { Boost }\end{array}$ \\
\hline 100 & 0,02 volt & 0,01 volt & 0,01 volt \\
\hline 200 & 0,03 volt & 0,01 volt & 0,01 volt \\
\hline 300 & 0,04 volt & 0,01 volt & 0,01 volt \\
\hline
\end{tabular}

Dari hasil pengukuran pada Tabel 3 dan Tabel 4 menunjukkan adanya pengaruh saklar terhadap tegangan di kapasitor dan tegangan di converter boost. Apabila saklar dalam kondisi off maka tidak arus yang mengalir ke converter boost dan tidak ada beban dari converter boost yang menghambat tegangan keluaran di kapasitor, sehingga ketika saklar diubah kondisinya dari off ke on maka tegangan yang disalurkan dari kapasitor ke baterai bisa dinaikkan oleh converter boost yang selanjutnya untuk mengisi daya handphone. Apabila saklar on maka ada arus yang mengalir menuju converter boost dan hambatan dari converter boost mempengaruhi tegangan di kapasitor, tegangan yang ada pada kapasitor akan langsung turun selain itu tegangan output di converter boost juga kecil dan tidak cukup untuk mengisi daya handphone.

\section{Pengisian Daya Baterai Handphone}

Karena kondisi saklar mempengaruhi tegangan output saat penekanan maka ketika pengisian baterai powerbank atau pada saat penekanan piezoelektrik berlangsung maka saklar harus dalam kondisi off dan saklar dalam kondisi on apabila digunakan untuk mengisi baterai handphone. Berikut hasil pengujian rangkaian powerbank piezoelektrik yang digunakan untuk mengisi daya handphone disajikan pada Gambar 8.

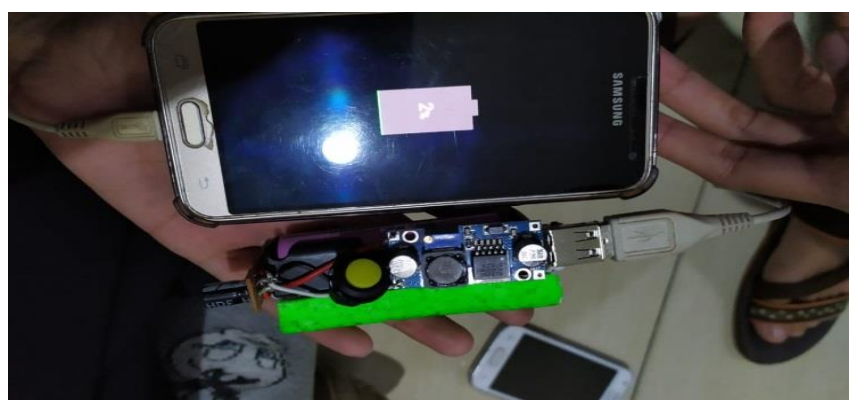

Gambar 8. Pengisian Daya Handphone dengan Rangkaian Simulator Powerbank Piezoelektrik
Dari hasil pengujian didapat bahwa powerbank ini bisa mengisi daya baterai handphone akan tetapi ada kekurangan yaitu kenaikan persentase daya handphone oleh powerbank piezoelektrik sangatlah lama dikarenakan arus yang terlalu kecil sehingga kenaikan daya baterai handphone konstan.

\section{KESIMPULAN}

\section{A. Kesimpulan}

Setelah melakukan penelitian alat powerbank piezoelektrik dapat disimpulkan bahwa tegangan dan arus yang dihasilkan piezoelektrik yang disusun secara paralel lebih besar daripada rangkaian seri. Tekanan yang diberikan kepada piezoelektrik berbanding lurus dengan tegangan yang di ukur pada kapasitor semakin banyak tekanan maka tegangan yang terukur semakin besar. Pemberian saklar sebelum modul XL6009 sangat berpengaruh terhadap output karena pada modul XL6009 terdapat beban yang menghambat. Untuk menghasilkan output yang besar maka saat pengisian baterai powerbank kondisi saklar off agar input tidak terbebani oleh modul, dan untuk mengalirkan arus untuk mengisi daya handphone maka saklar harus on. Penggunaan modul XL6009 membuat tegangan output menjadi stabil dan besar. Untuk mengisi daya baterai powerbank dibutuhkan waktu yang lama dalam menekan karena arus yang dihasilkan piezoelektrik terlalu kecil.

\section{B. Saran}

Setelah melakukan pengujian terdapat kendala-kendala dari piezoelektrik seperti tegangan yang dihasilkan besar tetapi arusnya kecil, sebagai saran perlu adanya pengembangan jenis piezoelektrik yang menghasilkan arus besar sehingga daya yang dikeluarkan besar sehingga dalam pengisian baterai powerbank waktunya lebih singkat.

\section{DAFTAR PUSTAKA}

[1] S, Astri. 2016. Rata-Rata Orang Indonesia Habiskan Waktu 5,5 Jam Main HP dari Bangun Hingga Beranjak Tidur. Available: http://www.tribunnews.com/lifestyle/2016/02/26/rata-rata-orangindonesia-habiskan-waktu-55-jam-main-hp-dari-bangun-hinggaberanjak-tidur.

[2] Anto, Budhi , Edy Hamdani dan Rizki Abdullah. Portable Battery Charger Berbasis Sel Surya. Jurnal Rekayasa Elektrika Vol. 11 , No. 1, April 2014, hal 19-24

[3] Kierby, Joelius. 2012. Pengisisan Baterai Handphone dengan Solar Cell. Yogyakarta : Universitas Sanata Dharma.

[4] Wijanto, Eddy dkk. Pengujian Sistem Konversi Energi Suara menjadi Energi Listrik Menggunakan Piezoelektrik. Techné Jurnal Ilmiah Elektroteknika Vol. 17 No. 1 April 2018 Hal 59 - 67.

[5] Madia, Aidil Akmal. 2017. Prototipe Alat Penghasil Listrik Dari Tekanan Mekanik Berbasis Piezoelektrik. Gowa : Universitas Hasanuddin.

[6] Hariyanto dan Agus R. Utomo. 2013. Studi Analisis Gelombang Tegangan Piezoelektrik. Depok: Universitas Indonesia.

[7] Usman dkk. Perancangan dan Pembuatan Trainer Penyearah Terkendari 3 Fasa. Jurnal Teknolodi Terpadu Vol. 5 No. 1 April 2017.

[8] Irpandi, Muhammad. 2015. Pengisian Baterai Handphone Berbasis Piezoelektrik. Batam : Politeknik Negeri Batam. 
[9] Maulana, Riza. 2016. Pemanfaatan Sensor Piezoelectric Sebagai Penghasil Sumber Energi pada Sepatu. Surakarta : Universitas Muhammadiyah Surakarta.

[10] Achmad Yani dan Gunawan. Rancang Bangun Perangkat Catu Daya Mandiri pada Laptop dengan Memanfaatkan Port USB dan Rangkaian Joule Thief. Journal of Electrical Technology Fakultas Teknik Universitas Islam Sumatra Utara, Vol 2, No 3(2017).
[11] Yulia, Efi, dkk.Polisi Tidur Piezoelektrik Sebagai Pembangkit Listrik dengan Memanfaatkan Energi Mekanik Kendaraan Bermotor. Jurnal Otomasi Kontrol dan Instrumentasi Vol 8 (1), 2016.

[12] Rinaldi, R Gustav, Muhammad Anton Kuncoro, dan Yesiana Arimurti. 2018. Perbandingan Pengisisan Kapasitor Oleh Piezoelektrik dengan Bateri, Prosiding SNFA (Seminar Nasional Fisika dan Aplikasinya) 2018. Surakarta: Universitas Sebelas Maret 